\title{
SELECTED FACTORS DETERMINING THE ADOPTION AND USE OF PARTICIPATORY BUDGETING IN CENTRAL AND EASTERN EUROPE
}

\author{
Daniel Klimovský1, Veronica Junjan², Juraj Nemec ${ }^{3}$
}

\begin{abstract}
This is a summary article of the SJPS thematic issue on participatory budgeting in the Central and Eastern European region. Its authors provide an overview of the diffusion of participatory budgeting, and they classify relevant countries in terms of the pace of this diffusion into four different groups: frontrunners, early majority, later majority, and lagging adopters. In addition, they uncover various diffusion mechanisms that have been used. Since the research articles included in this thematic issue unpack various factors that influence the diffusion of the innovative practice of participatory budgeting in the specific settings of Central and Eastern Europe, the main goal of this article is to sum up their crucial findings and formulate several conclusions, including a few avenues for further research. A clear majority of countries in the region have already collected a relevant amount of experience with the adoption and further use of participatory budgeting. An analysis of the individual experiences reveals that the position and characteristics of mayors, organizational resources, and available capacities, as well as the quality of public trust, are likely to be important factors that determine the adoption and use of participatory budgeting in the region.
\end{abstract}

KEY WORDS: Participatory budgeting, Democratic innovation, Policy diffusion, Central and Eastern Europe

\section{INTRODUCTION}

Participatory budgeting (PB) has become an interesting innovation of democratic budgeting since its introduction in Porto Alegre. Although it

\footnotetext{
${ }^{1}$ Faculty of Arts, Comenius University in Bratislava, Gondova 2, 81102 Bratislava, Slovak Republic / Faculty of Economics and Administration, University of Pardubice, Studentská 84, 53210 Pardubice 2, Czech Republic. E-mail: daniel.klimovsky@uniba.sk, ORCID: 0000-00020312-2842.

${ }^{2}$ Faculty of Behavioural, Management and Social Sciences, University of Twente, Drienerlolaan 5, 7522 Enschede, Netherlands. E-mail: v.junjan@utwente.nl.

${ }^{3}$ Faculty of Economics and Administration, Masaryk University in Brno, Lipová 507/41a, 602 00 Brno, Czech Republic / Faculty of Economics, Matej Bel University in Banská Bystrica, Tajovského 10, 97590 Banská Bystrica, Slovak Republic. E-mail: juraj.nemec@umb.sk, ORCID: 0000-0002-5881-7422.
} 
travelled almost exclusively around Latin America in the 1990s, it arrived in some Western European countries approximately at the turn of the millennium (Sintomer, Herzberg, Röcke, 2008). This innovation took root in some urban centres in Europe in the early 2000s; however, their approaches were experimental rather than being based on some clear vision or strategy. A slower increase in the PB experience has been typical for Central and Eastern European (CEE) countries. It is therefore no surprise that there are still many unanswered questions regarding the diffusion, implementation, and impacts of this democratic innovation of budgeting in this region.

The unanswered questions concerning the gradual increase in various initiatives focusing on PB in CEE countries have attracted notable research interest. Despite this attention, most research activities remained fragmented; the current project therefore aims to support a more systematic approach. To this end, scholars from various fields were invited to contribute to a discussion by presenting their latest research findings.

A call for papers was announced in February 2021. Subsequently, two events were organized for researchers eventually interested in contributing to the thematic issue. The first event was a conference entitled "Participatívne rozpočtovanie: užitočný nástrojalebo módny hit?" ("Participatory Budgeting: A Useful Tool or Just a Fad?"), and it was held as a hybrid event in Bratislava, Slovakia, from 24 to 25 June 2021 . The programme of the first conference day consisted of several presentations. The presenters discussed experiences from several European countries: Portugal, the United Kingdom, Germany, Finland, Russia, Estonia, Latvia, Lithuania, Poland, Germany, and the Czech Republic. The second conference day focused on the Slovak experience with PB. A second event was organized as a part of the twenty-ninth NISPAcee Annual Conference from 22 to 23 October 2021 in Ljubljana, Slovenia. A joint session aimed to facilitate the development of more intensive research relationships between researchers from two NISPAcee working groups in the field of PB: WG1 on Local Government and WG5 on Public Finance and Public Financial Management. The joint session, entitled "Participatory Budgeting in Central and Eastern Europe: A Useful Tool or Trend?", was coordinated by Daniel Klimovský and Juraj Nemec; they invited the authors of eleven proposals to register for the session and present their papers. Except one comparative paper, most of the presented research tackled the PB experiences in individual countries in the CEE region (Poland, Finland, Romania, Slovenia, Lithuania, Hungary, Germany, and Slovakia).

In total, nine research manuscripts were submitted. The guest editors decided to recommend seven of them for a standard double-blind review 
procedure. Five recommended manuscripts ended up being successful. The main goal of this article is to sum up their central findings and formulate possible avenues for further research. The article consists of four parts. The first part outlines the pace and diffusion mechanisms linked to PB across the whole region. In the second part, we point out the limits of the current state of knowledge in this field with special regard to research focusing on the CEE region. The third part offers the main findings of the research articles included in this thematic issue. Finally, we sum up these findings and formulate possible avenues for further research.

\section{THE DIFFUSION OF PARTICIPATORY BUDGETING IN CENTRAL AND EASTERN EUROPE}

$\mathrm{PB}$ is a direct-democracy approach to budgeting. It offers citizens an opportunity to learn about government operations, and to deliberate, debate, and influence the allocation of public resources. It is a tool for educating, engaging, and empowering citizens and strengthening demand for good governance (Shah, 2007b, p. 1). According to Fölscher (2007, p. 129), PB initiatives in the CEE region faced the following historical legacies: (1) citizens had been detached from decision-making for a long time and they were receivers of public services rather than active co-creators; (2) autonomous self-government at the sub-national levels and various collective forms of political and social organization were a relatively new concept; (3) despite decentralization waves, responsibilities and powers remained ambiguously assigned to sub-national governments which had not enjoyed real fiscal autonomy; (4) revenues and expenditures of sub-national governments were often imbalanced, and subsidies or transfers from the central level were usually unreliable; (5) the local autonomy of sub-national governments in decision-making was also limited; and (6) there was general dissatisfaction with the quality of local services - citizens did not trust the government yet, which were not confident enough to take the initiative themselves. These legacies were confirmed by other researchers, who also highlighted clear differences among countries in the CEE region (Kuhlmann, Bouckaert eds., 2016; Wollmann, Koprić, Marcou eds. 2016; de Vries, Nemec, Špaček eds. 2019; Ladner et al. 2019; Geissler Hammerschmid, Raffer eds. 2021). Given this diversity, it is possible to understand the different attitudes of relevant stakeholders in CEE countries. The innovation diffusion perspective proposed by Rogers (2010) suggests that the distribution of innovations is spread along a normally distributed curve, and that the actors adopting 
a particular innovation are broadly grouped into being (1) innovators, (2) early adopters, (3) the early majority, (4) the later majority, and (5) laggards (Rogers, 2010, p. 22). Given that PB arguably requires additional resources in terms of legitimacy and the development of political support as a tool of social innovation before it is adopted, it seems feasible to group the early adopters and the early majority together in the case of its adoption across the CEE region in order to allow for the time effects to take place. Taking this adjustment into account, the spread of PB across the CEE region in terms of the pace of its adoption can thus be divided broadly into four groups of countries: (1) frontrunners (innovators), (2) the early majority, (3) the later majority, and (4) lagging adopters.

Countries such as Albania, Belarus, Bulgaria, and Russia became the frontrunners in terms of the adoption and spread of PB throughout the CEE region, with the first PB initiatives occurring there before 2010. The first PB initiatives started in Bulgaria in the early 2000s, in Albania in 2004, in Belarus in 2006, and in Russia in 2007. A crucial and common feature for all cases was external financial support and organizational assistance. These initiatives were driven by the activities of external stakeholders (i.e. international donors) such as the World Bank in the Albanian and Russian cases and the EU alongside other European institutions in the case of Belarus (Afanasiev, Shash, 2022; Goldfrank, 2012; Krivorotko, Sokol, 2022). The Albanian case is very interesting because, after completing the pilot projects supported by the World Bank, the innovation spread throughout the country without any further external support. Indeed, Albania had the largest number of participatory budgets in Southeast Europe (Sintomer et al. 2010, p. 40). In Bulgaria, the first community-based investment programme for municipal development (in Svishtov) was implemented with the assistance of the Local Government Initiative and international experts and was cofinanced through a USAID grant (Driscoll, Laskowska, Eneva, 2004).

The group of the early majority includes several members of the EU (Croatia, Czech Republic, Estonia, Poland, Romania, and Slovakia) where the first successful PB initiatives were adopted before 2015. A common feature of all rapid adopters was that the PB adoption process was very fragmented and rather experimental in comparison to other examples of social innovations observed in the region, which were characterized by strong external support that was usually followed by a dynamic spread. In addition, this innovation was implemented in these countries thanks to the activities of some NGOs and the engaged representatives of a few local governments. Finally, the adoption of PB was accompanied by high media 
coverage and related public expectations (Džinić, 2022; Sedmihradská, Kukučková, Bakoš, 2022; Klotz, 2022; Kozłowski, Bernaciak, 2022; Krenjova, Reinsalu, 2013; Boc, Lazăr, 2022; Murray Svidroňová, Klimovský, 2022). Despite these commonalities, the individual trajectories in terms of the further spread of PB vary a lot. For instance, several relatively strong NGOs remain the main policy entrepreneurs in this field in the Czech Republic. In Slovakia, the Office of the Government Plenipotentiary for Civil Society Development recently became one of the main policy entrepreneurs in this field (Klimovský et al. 2021). In addition, Slovakia is the only member of this group where a national charter of good PB was announced and offered to all local governments interested in adopting or using PB (Klimovský, Hrabinová, 2021). A national regulation introducing compulsory PB for all county towns and cities was approved in Poland at a time when more than 200 local governments had already adopted it (Popławski, Gawłowski, 2019; Kurdyś-Kujawska, Kwiatkowski, Oklevik, 2019; Madej, 2019).

The later majority - comprising Hungary, Lithuania, North Macedonia, Moldova, Serbia, Slovenia, and Ukraine - is a heterogeneous group of countries. Although local governments in these places began to experiment with PB approximately in the same period (2015 to 2019), they experienced different drivers and the further spread of this democratic innovation presented different stories. For instance, the idea of PB was brought to Serbia thanks to externally financed projects; support was given from USAID as well as from the development agencies of Norway and Switzerland (Milosavljević, Spasenić, Benković, 2022). Similarly, the Fiscal Accountability, Sustainability, and Transparency Network initiative in North Macedonia was funded by USAID through the Civic Engagement Project in 2016; thanks to this support, PB has been adopted and used in eight municipalities there over the last three years (USAID, 2020). The first Slovenian adoption was expected to be the Maribor initiative in 2015; however, due to a combination of circumstances, this initiative was not successfully implemented and the first successful Slovenian adoption of PB actually happened one year later (Klun, Benčina, 2022). By 2019, more than 20 local governments in Slovenia had introduced this innovation (Klun, Stare, 2020). PB has been adopted by just a few local governments in Hungary, and it is not generally considered to be a popular innovation (Klotz, 2022). A specific trajectory can be observed in Lithuania. The very first PB initiative there was implemented in 2013 within the education policies at the school level. The very first initiative at the local government level occurred in 2018, when PB was adopted by the local government of 
Alytus. This was a real turning point, because the spread of this democratic innovation has been much faster there than in other late innovators since its first adoption (Dvorak, Burbulyte-Tsiskarishvili, 2021). As for Ukraine, the Polish-Ukrainian Cooperation Foundation introduced PB activities in Chernihiv and several other cities based on earlier initiatives from Poland. The foundation conducted a series of seminars and organized in-service training in Poland for Chernihiv city officials and community activists involving experts from Warsaw and Lodz. The spread of this democratic innovation was rapid, with PB being adopted by several cities, including Cherkasy, in 2015; by the end of 2016, PB was being implemented by approximately fifty cities in Ukraine (Khutkyy, Avramchenko, 2019). The Polish experience was also used to introduce PB to Moldova. The first case of PB adoption there occurred in Bălți in 2016, and later it was followed by other towns and cities, including Chișinău (Melenchuk, 2021).

Latvia is a case of a lagging adopter, because PB was not introduced there as a practical budgetary innovation before 2020; however, thanks to the outputs of the Empowering PB in the Baltic Sea Region (EmPaci) project, which is financially supported by the European Regional Development Fund and the Russian Federation, the Latvian Cabinet of Ministers approved the Conceptual Report of the Ministry of Environmental Protection and Regional Development of Latvia on the introduction of PB in May 2020 (Social Innovation Centre, 2020).

As apparent, there is a significant diversity among CEE countries in terms of the diffusion of PB. The frontrunners enjoyed significant support from international donors such as the World Bank. Although the World Bank had promoted PB as a recipe for local governments across the globe (Goldfrank, 2012, p. 14), its assistance in the CEE region remained directed at a smaller group of countries due to the time when this was taking place, i.e. in the early 2000 s, when the EU accession efforts influenced the behaviour and focus of many governments. A significant role was played by various NGOs, which introduced or helped introduce PB to CEE countries. They were clearly inspired by the origins of PB from Porto Alegre. Public authorities generally remained resistant at the beginning of the diffusion processes, but in some countries (Poland, Slovakia, Slovenia, and Ukraine), some authorities began to play an important role in the later stages of this diffusion. It is important to stress that project-based PB prevails in the CEE region (Nemec, Špaček, de Vries, 2022), regardless of the pace of diffusion or the driving forces.

The theory of policy diffusion can also help us understand the adoption and introduction of PB in various countries (Goldfrank, 2012; Oliveira, 
2017; Wampler, Mcnulty, Touchton, 2018). Braun and Gilardi (2006) accept that any public reform or innovation can be the result of independent decision-making done by actors whose activities are determined by relevant circumstances in their countries; on the other hand, any public reform or innovation can be imported through policy diffusion - i.e. through a process where choices are interdependent, meaning that a government's choice influences the choices made by others and that conversely government choices can be influenced by the choices made by others (Braun, Gilardi, 2006, p. 299). Taking these ideas into account, we can distinguish between the political diffusion mechanisms - (1) learning, (2) competitive and cooperative interdependence, (3) coercion, (4) common norms, (5) takenfor-grantedness, and (6) symbolic imitation - both among and within individual countries.

According to Meseguer (2004), the mechanism of learning is defined as the acquisition or gathering of new information that is relevant when adjusting beliefs about the outcomes of a new policy. This mechanism has been common in diffusing PB within countries in the CEE region, but one can identify it between countries as well. (For example, the Polish experience was relevant for diffusing PB in Moldova and Ukraine.) At this point, it is necessary to stress that bounded learning based on a heuristic approach was applied instead of fully rational learning. The focus on bounded learning can be justified by the need to account for the specifics of the local context, which can be manifested in terms of institutional maturity and administrative and policy capacity. Although Simmons and Elkins (2004) interlink competitive interdependence with government efforts to attract economic activity, in the case of PB this is a form of higher civic engagement. The mechanism of competitive interdependence could be seen, for instance, in the case of diffusing PB among regions in Slovakia. More precisely, the adoption of this innovation, focusing on the improvement of the quality of local democracy and enhancing public participation at a regional level, was immediately followed by similar incentives by regional governments in neighbouring regions. According to Lazer (2001), the mechanism of cooperative interdependence leads to compatible policies, and benefits can be based on a common standard. An illustrative example is provided by the diffusion of PB through the adoption of common digital tools by local governments in the Czech Republic. Coercion is defined as the imposition of policies on national governments by powerful international organizations or powerful countries (Braun, Gilardi, 2006, p. 309). Of course, neither an international organization nor a powerful country has employed top-down 
pressure to spread PB across the CEE region; however, this mechanism can be used in order to understand the diffusion of PB among county towns and cities in Poland. Although other mechanisms of policy diffusion were initially used, coercion can be identified in Poland since the approval of the national regulation that led to the compulsory adoption and use of this democratic innovation.

Existing networks can produce sets of common norms, which consequently determine the behaviour of other actors. The mechanism of common norms frequently seems present in terms of the adoption and further use of $\mathrm{PB}$ across the CEE region. For instance, international projects (e.g. the EmPaci Project in the Baltic Sea region) as well as various national initiatives (e.g. the Fiscal Accountability, Sustainability, and Transparency Network in North Macedonia and the National Network of Healthy Cities of the Czech Republic) have undoubtedly affected the adoption and use of PB models. The Charter of Good Participatory Budgeting, approved in Slovakia in November 2021, could also be understood as a set of common norms, which may well lead to similar behaviour by local governments interested in this democratic innovation. In addition, the activities of various international organizations, including the World Bank and USAID, could lead to the adoption of common norms, and these organizations could be defined as agents of socialization (Finnemore, Sikkink, 1998, p. 902). Having said that, financial support and organizational assistance from these organizations could lead to the mechanism of taken-for-grantedness in some cases. More precisely, PB could be taken for granted by many local actors in countries like Belarus due to the political status of international organizations; local actors have interlinked such a democratic innovation as PB with high effectiveness and other benefits without making any deeper impact assessment. The mechanism of symbolic imitation is not rare in countries of the CEE region if one looks at the diffusion of PB. In Romania and Slovakia, there have been numerous cases where local governments have only pretended their activities were sufficient. Instead of properly adopting a PB model, they preferred to partially implement some elements of chosen models and intensely use the PB label for the purposes of political marketing regardless of its actual effectiveness or any other outcomes (Costea, Ilucă, 2021; Cuglesan, 2021; Murray Svidroňová, Klimovský, 2022). 


\section{PARTICIPATORY BUDGETING AS A RESEARCH TOPIC}

Large-scale comparative studies concerning PB are rare (Oliveira, 2017; Sintomer et al. 2008; 2010; 2013) and have mostly focused on Latin American, North American, or West European experiences. A clear majority of the existing literature consists of country studies and case studies. The evolution of research in this field has closely followed practical experiences with the adoption and further spread of PB in various regions. Unsurprisingly, the roots of research are linked to the Porto Alegre case (Abers, 1998; De Sousa Santos, 1998). The further diffusion of PB attracted the immediate interest of numerous researchers in Latin America as well as in North America (Cameron, 2009; Hernandez-Medina, 2007; Hordijk, 2005; Nylen, 2002; Pinnington, Lerner, Schugurensky, 2009; Wampler, 2004; 2007; Wampler, Avritzer, 2005).

As a democratic innovation in the field of public budgeting, PB spread across Latin America thanks to the activities of left-oriented political parties (Goldfrank, 2007). By contrast, it travelled from Latin America thanks to the activities of various NGOs, the international engagement of local governments or their representatives, and a few international donors such as the World Bank (Teivainen, 2010; Shah ed. 2007a). Its arrival in Europe was immediately challenged because of different political, administrative, and societal circumstances (Röcke, 2014). Whereas the original PB model varied only moderately in the conditions of different countries in the decade following its very first adoption in Porto Alegre, the heterogeneous European environment required rapid and multiple variations.

Taking into account the contribution by Sintomer, Herzberg and Röcke (2008), who analysed the spread of PB across Europe, the diffusion of this democratic innovation has not been smooth. One can identify innovators (such as France, Germany, Italy, Portugal, and Spain) where PB practices occurred before 2005 , as well as several innovation followers and numerous countries where PB was adopted significantly later. Numerous lagging countries are located in the CEE region, and thus, paradoxically, they started to adopt this innovation at a time when PB was being strongly criticized and was even in decline - in more experienced places (Melgar, 2014; Barros, Sampaio, 2016; Wampler, Goldfrank, 2022). From this perspective, it is fascinating and very important to uncover the drivers and their motivations as well as all of the relevant features of the models of PB that have been adopted in the countries of the CEE region. 
Krenjova and Raudla (2013) offered a comparative assessment of the first experience with the adoption and use of PB in the 'new democracies' in CEE. They assessed the existing PB models, matched the various models to different constellations of contextual variables, and investigated the applicability of PB under the circumstances of the new democracies. Their analysis showed that the limited financial autonomy of local governments in these countries, combined with the prevailing political culture and rather weak civil societies, determined the existence of the main challenges for the successful adoption and use of this democratic budgetary innovation among CEE countries. In addition, they saw PB as a support tool to encourage participatory culture and foster genuine decentralization in the region. Although one can find a few small-scale comparisons whose authors dealt mainly with institutional settings (Džinić, Murray Svidroňová, MarkowskaBzducha, 2016; Fölscher, 2007; Kersting et al. 2016; Mączka et al. 2021; Radzik-Maruszak, Bátorová, 2015; Lehtonen, 2021), numerous country studies (Brabec, 2019; Džinić, 2018; Garaj, Bardovič, 2020; Gondášová, Svidroňová, 2016; Kempa, Kozłowski, 2020; Kukučková, Bakoš, 2019; Milosavljević et al. 2020; Minárik, 2020; Sześciło, 2015) and case studies (Balážová, 2021a; Bardovič, 2021; Bednarska-Olejniczak, Olejniczak, 2016; Boc, 2019; Gašparík, 2021; Hrabinová, 2020; Kociuba, Rabczewska, 2019; Krenjova, Reinsalu, 2013; Mærøe et al. 2021; Polko, 2015; Švaljek, Rašić Bakarić, Sumpor, 2019; Tomášková, Buzková, 2020; Zapletalová, Soukop, Šaradín, 2020) have prevailed. It is also possible to find studies whose authors evaluated the legal conditions of individual CEE countries from the perspective of the adoption or continued use of PB (Birskyte, 2013; Šramel, 2018; Zawadzka-Pąk, Tomášková, 2019). Also, the durability and resilience of PB under the uncertain circumstances of the COVID-19 pandemic have recently been analysed (Baranowski, 2020; Bardovič, Gašparík, 2021; Popławski, 2020).

One of the most comprehensive research contributions has taken the form of a recent collection of country studies focusing on PB initiatives in the CEE region (de Vries, Nemec, Špaček eds. 2022). Among other things, this collection contains overviews of the adoption and further use of PB in several CEE countries: Belarus, Croatia, the Czech Republic, Hungary, Poland, Romania, Russia, Serbia, Slovakia, and Slovenia. For more information, see the book review by Balážová (2021b) that is included in this issue. 


\section{SELECTED FACTORS DETERMINING THE SCALE AND SUCCESS OF PARTICIPATORY BUDGETING: A SUMMARY OF FINDINGS FROM THIS THEMATIC ISSUE}

The articles included in this issue deliver critical added value to the discussion about factors determining the pace and quality of the diffusion of PB in the CEE region. The article investigating the case of Slovenia (and implicitly the article analysing the case of Serbia), which stresses the factor of political will, and an article focusing on the Czech Republic which narrowly focuses on three conditions determining the failures of PB at a local level and points out the factor of political support, suggest that the personality of the main decision-maker(s) should be seen as a critical determinant of the successful adoption and further use of PB. In addition, this issue includes an article analysing the preliminary impacts of an innovative voting online platform called Democracy 2.1 that recently became popular among local governments in the Czech Republic. This issue also offers a comparative study that focuses on some institutional settings and recent developments linked to PB initiatives in the Czech Republic, Hungary, Poland, and Slovakia (the Visegrad Four). Last but not least, we decided to invite a colleague of ours to write a review of a new book edited by de Vries, Nemec, and Špaček entitled "International Trends in Participatory Budgeting: Between Trivial Pursuits and Best Practices" (Balážová, 2021b). Since the contents of this edited book address the experiences with PB in CEE countries in particular, the rationale here was direct and simple: the authors of the research articles in this issue would tackle the issues that clearly overlapped with the contents of the book. We believe that the edited book and this thematic issue significantly contribute to understanding the evolution of PB in the CEE environment.

Šabovic, Milosavljević and Benković (2021) deal with citizens as another critical stakeholder in the PB process, and they look at their will to participate. Based on the analysis of the dominant participation models in the local financial decision-making process (self-imposed contribution, PB, and civic crowdfunding), their data suggest that there are two main factors that explain low participation: a lack of knowledge about participation in financial decision-making and a lack of interest in participation. Moreover, Šabovic, Milosavljević and Benković state that these narrowed-down factors illustrate the level of distrust in politics and in society in general.

Klun and Benčina (2021) also deal with institutional factors, which influence the likelihood of the adoption of PB in a country where this local 
democratic innovation is voluntary and still new. According to their findings, mayors in Slovenia who hold their office for several terms are more likely to initiate and support PB initiatives. These findings suggest that the length of office, coupled with the experience and organizational competence of the person in this leadership position, are clear organizational determinants for initiating and implementing the PB practices. Alongside the personality of a mayor, they tested many other independent variables such as the level of local democracy, the knowledge capacity of local government, the differences between immigrants and emigrants, demography, the health situation in the municipality, social cohesion, the level of economic development and achieved economic growth, and the organizational and financial capability of local government. Within the Slovenian settings, Klun and Benčina propose six indicators that affect the likelihood of PB adoption, and they prove the influence of four determinants on an effective decision to adopt PB. In addition to confirming the importance of a mayor's personality, they found that the political impact is expressed through incumbency and that the influence of social demographic determinants is covered by the immigration surplus, the indicator of physical fitness, and the share of older people receiving home help. The other two determinants - the economic level and the municipal capability - influence PB adoption with the labour market index and financial independence coefficient. Of all the relevant factors defined by their study, fiscal capacity is mentioned in particular by many other studies (Nemec, Špaček, de Vries, 2022).

Soukop, Šaradín and Zapletalová (2021) offer an analysis of the causes of the failure of PB at the local level in the Czech Republic. They employ a case study method focusing on PB in the capital city district of Prague 7. They point out three scope conditions for PB to be functional: (1) political support; (2) the provision of sufficient financial resources, which also serve as a subjective psychological factor and motivator in municipalities where public participation is underdeveloped; and (3) the existence of sufficient know-how in the field of PB and the employment of a suitable method for the adoption and further use of PB in the municipality. Soukop, Šaradín and Zapletalová assume that there is a mutual interdependence among these conditions, and they try to demonstrate the complex nature of the observed project failure.

Compared to the previous articles with a dominant focus on institutional factors, the article by Kukučková and Poláchová (2021), also focusing on the Czech Republic, deals with a specific technical factor. Since 2015, an online voting platform using the Democracy 2.1 (D21) method has spread 
among Czech local governments; it has become a well-known digital tool for polling within PB. This method enables voters to use more positive and negative votes when certain conditions are met; this distinguishes this tool from other methods or tools that usually simply calculate the total number of votes. The authors tested a hypothesis that the local governments using the D21 voting method would have a higher participation rate in voting on PB projects than local governments using voting methods that are not in line with the definition of the D21 voting method. Their findings confirm that local governments with the D21 method and its modified form generally register a higher voter turnout in PB than local governments where this method has not been adopted yet.

Mikuš, Brix and Šmatlánek (2021) offer a comparative study focusing on selected experiences with PB in the Visegrad Four. They stress that PB is a relatively widespread tool in Poland, Slovakia, and the Czech Republic but that Hungary is a country where the evolution of the broader adoption of this tool is still at the beginning. This is in compliance with our classification of these countries: Poland, Slovakia, and the Czech Republic are members of the early majority; whereas Hungary is a member of the later majority. An analysis of the further spread of this innovation across these countries led to the finding that the COVID-19 pandemic had become a real game changer and that $\mathrm{PB}$ initiatives have been challenged by very uncertain circumstances and volatile turbulences since the beginning of the pandemic.

\section{CONCLUSIONS}

The articles included in the thematic issue bring a very nuanced and diverse set of contributions to the literature on PB. These investigations are located in the CEE region as a group of countries with a diverse range of institutional, political, and administrative experiences with regard to adopting and implementing PB (Nemec, Špaček, de Vries, 2022). Despite these diverse experiences, several factors seem to emerge from a careful reading of the results reported in the research articles. These factors refer to the importance of the position and characteristics of a mayor, the available organizational resources and capacity, and the level of public trust.

Given the traditional expectations of a mayor as being a "parent figure" in local government settings, the mayor's role as a determinant factor might not come as a big surprise. Most CEE countries have direct mayoral elections, and mayors are seen as the administrative and political heads of local governments (Heinelt eds. 2018; Gendzwiłł, Kjær, Steyvers, 2022). 
Nonetheless, the articles provide a solid basis for the nuancing of mayoral characteristics that are conducive to the adoption and use of PB; these include political orientation, the length of experience in office, and managerial experience and skills. A particular research focus for the future could be the impact of the length of experience in office or incumbency status. What is the 'optimal' length of experience in the office for the facilitation of new PB initiatives and the continuation of existing ones? Often, there is a limit on the number of terms as established by law (and with good reason) as a way of counteracting corruption and facilitating democratic alternation. What do such limits mean for the development and transfer of skills and specific knowledge for the position of mayor? In addition, the relationship between the willingness to adopt PB and the specific characteristics (e.g. political affiliation, gender, and field of education) of the main decision-makers, including mayors, should be investigated in a deeper way (Maškarinec, 2020; Maškarinec, Klimovský, 2016).

The organizational resources and capacity available at the local level are also a crucial factor for the adoption and use of PB practices in the CEE setting. These organizational resources refer to information available on the practices of implementing PB, the availability of trained human resources, and a dedicated budget within the specific local government organization that can be allocated to develop, monitor, and implement the process as well as the time path that is necessary for the initiation and implementation. Such a process takes time to start and for results to be visible to the population and elected local representatives. Given the regularity of the electoral cycle of four to five years and the focus on results, the importance of allocating sufficient resources and the building of adequate policy, organizational, and administrative capacities (Wu, Ramesh, Howlett, 2015; Junjan, 2020a) that are needed for the process are an urgent matter for further investigation.

Taking available resources and capacities into account, the COVID-19 pandemic could be considered an unprecedented challenge for governments at all levels, not excluding the governments in CEE countries. In spite of some successes at the beginning of the pandemic, later developments have exposed their vulnerability and governments in these countries have struggled a lot. The pandemic necessarily impacted the behaviour and decision-making of local governments and the durability of ongoing PB initiatives as well as the evolution of new initiatives within this context (Baranowski, 2020; Bardovič, Gašparík, 2021; Popławski, 2020).

Finally, public trust in governments, which is notoriously low in CEE countries (Bouckaert, Nakrošis, Nemec, 2011; Nemec, 2014), requires 
additional attention. General literature and publicly available data (such as Eurostat monitors) illustrate the relatively low level of public trust in government and in politics. Beyond discussing the situation, the articles in this issue illustrate just how important it is to carefully consider specific strategies at the local level for communicating with the public and building the trust (Tippelt, 2017). PB seems to be particularly suitable as a testing ground for the development of long-term measures leading to the creation of public trust, given the proximity of the results and the interest in the efficient and effective spending of public money at a local level.

All in all, the articles included in this issue provide a very promising foundation for further research into the specifics of the adoption, use, and monitoring of PB in CEE. This setting is also of particular importance for broader theoretical development, because the countries in the region have developed a high level of experience with adopting reforms oriented towards strengthening policy and organizational and administrative capacity in local government during the time of re-building political democratic regimes (Junjan, 2020b). These countries' experiences thus provide a set of crucial insights into the theoretical development of models regarding the introduction and implementation of reforms in government and administration.

\section{Acknowledgement:}

This work was supported by the Slovak Research and Development Agency under the Grant No. APVV-19-0108: "Innovations in Local Government Budgeting in Slovakia".

\section{REFERENCES}

ABERS, R. (1998). From Clientelism to Cooperation: Local Government, Participatory Policy, and Civic Organizing in Porto Alegre, Brazil. In: Politics \& Society. Vol. 26, No. 4, pp. 511-537. DOI: https://doi.org/10.11 77/0032329298026004004.

AFANASIEV, M. and SHASH, N. (2022). Participatory (Initiative) Budgeting in the Russian Federation. In: De Vries, M. S., Nemec, J. and Špaček, D. eds. International Trends in Participatory Budgeting: Between Trivial Pursuits and Best Practices. Cham: Palgrave Macmillan, pp. 205-228. DOI: https:// doi.org/10.1007/978-3-030-79930-4_11. 
BALÁŽOVÁ, M. (2021a). Youth Engagement in Participatory Budgeting: Case Study of Kutná Hora (2019-2020). In: Slovak Journal of Public Policy and Public Administration. Vol. 8, No. 2, pp. 53-74.

BALÁŽOVÁ, M. (2021b). De Vries, M. S., Nemec, J., and Špaček, D. (2022). International Trends in Participatory Budgeting: Between Trivial Pursuits and Best Practices, Cham: Palgrave Macmillan, 2022, ISBN 9783-030-79929-8. In: Slovak Journal of Political Sciences. Vol. 21, No. 2, pp. 256-261. https://doi.org/10.34135/sjps.210207.

BARANOWSKI, J. (2020). Participatory Budget and the Sars-Cov-2 Pandemic in Poland. In: Transylvanian Review of Administrative Sciences. Vol. 16, Special Issue 2020, pp. 24-37. DOI: https://doi.org/10.24193/tras. SI2020.2.

BARDOVIČ, J. (2021). Participácia obyvatelov na participatívnom rozpočte v krajských mestách. In: Duffeková, K., Feketeová, B. and Lörincová, K. eds. 2020: Začiatok dekády zmien? Zborník príspevkov. Košice: Univerzita P. J. Šafárika v Košiciach, pp. 250-266.

BARDOVIČ, J. and GAŠPARÍK, J. (2021). Enablers of Participatory Budgeting in Slovakia During the COVID-19 Pandemic. In: Scientific Papers of the University of Pardubice, Series D: Faculty of Economics and Administration. Vol. 29, No. 1, Art. No. 1248. DOI: https://doi. org/10.46585/sp29011248.

BARROS, S. A. R. and SAMPAIO, R. C. (2016). Do Citizens Trust Electronic Participatory Budgeting? Public Expression in Online Forums as an Evaluation Method in Belo Horizonte. In: Policy \& Internet. Vol. 8, No. 3, pp. 292-312. DOI: https://doi.org/10.1002/poi3.125.

BEDNARSKA-OLEJNICZAK, D. and OLEJNICZAK, J. (2016). The Participatory Budget of Wrocław as an Element of the Smart City 3.0 Concept. In: 19th International Colloquium on Regional Sciences. Conference Proceedings. Brno: Masaryk University, pp. 760-766. DOI: https://doi.org/10.5817/ CZ.MUNI.P210-8273-2016-97.

BIRSKYTE, L. (2013). Involving Citizens in Public Decision Making: The Case of Participatory Budgeting in Lithuania. In: Financial Theory and Practice. Vol. 37, No. 4, pp. 383-402. DOI: https://doi.org/10.3326/fintp.37.4.3. BOC, E. (2019). The Development of Participatory Budgeting Processes in Cluj-Napoca. In: Transylvanian Review of Administrative Sciences. Vol. 15, No. 58 E, pp. 38-51. DOI: https://doi.org/10.24193/tras.58E.3.

BOC, E. and LAZĂR, D. T. (2022). Participatory Budgeting in Romania. In: De Vries, M. S., Nemec, J. and Špaček, D. eds. International Trends in Participatory Budgeting:Between Trivial Pursuits andBestPractices. Cham: 
Palgrave Macmillan, pp. 187-204. DOI: https://doi.org/10.1007/978-3030-79930-4_10.

BOUCKAERT, G., NAKROŠIS, V. and NEMEC, J. (2011). Public Administration and Management Reforms in CEE: Main Trajectories and Results. In: The NISPAcee Journal of Public Administration and Policy. Vol. 4, No. 1, pp. 9-29. DOI: https://doi.org/10.2478/v10110-011-0001-9.

BRABEC, D. (2019). Participatory Budgeting in the Czech Republic between 2014 and 2018. In: Annales Universitatis Mariae Curie-Skłodowska, sectio K- Politologia. Vol. 26, No. 2, pp. 91-101. DOI: https://doi.org/10.17951 /k.2019.26.2.91-101.

BRAUN, D. and GILARDI, F. (2006). Taking "Galton's Problem" Seriously: Towards a Theory of Policy Diffusion. In: Journal of Theoretical Politics. Vol. 18, No. 3, pp. 298-322. DOI: https://doi. org/10.1177/0951629806064351.

CAMERON,J.D. (2009). "Development is a Bag of Cement”: The Infrapolitics of Participatory Budgeting in the Andes. In: Development in Practice. Vol. 19, No. 6, pp. 692-701.DOI: https://doi.org/10.1080/09614520903026835. COSTEA, I. M. and ILUCĂ, D. M. (2021). The Obligation to be Silent: Citizen Intervention in Budgetary Procedures. A paper presented at the 29th NISPAcee Annual Conference in Ljubljana, 22-23 October 2021.

CUGLESAN, N. (2021). Local Governance and Participatory Democracy: Experiments of Digital Participatory Budgeting in Romania. A paper presented at the 29th NISPAcee Annual Conference in Ljubljana, 22-23 October 2021.

DE SOUSA SANTOS, B. (1998). Participatory Budgeting in Porto Alegre: Toward a Redistributive Democracy. In: Politics \& Society. Vol. 26, No. 4, pp. 461-510. DOI: https://doi.org/10.1177/0032329298026004003.

DE VRIES, M. S., NEMEC, J. and ŠPAČEK, D. eds. (2019). Performance-Based Budgeting in the Public Sector. London: Palgrave Macmillan. DOI: https:// doi.org/10.1007/978-3-030-02077-4.

DE VRIES, M. S., NEMEC, J. and ŠPAČEK, D. eds. (2022). International Trends in Participatory Budgeting: Between Trivial Pursuits and Best Practices. Cham: Palgrave Macmillan. 317 pp. DOI: https://doi.org/10.1007/9783-030-79930-4.

DRISCOLL, J., LASKOWSKA, A. and ENEVA, M. (2004). Svishtov: A CommunityBased Investment Program for Municipal Development. Sofia: Local Government Initiative. 25 pp.

DVORAK, J. and BURBULYTE-TSISKARISHVILI, G. (2021). Lessons Learnt from Evidence-Based Participatory Budgeting in Lithuania: The Case 
of the EmPaci Project. A paper presented at the 29th NISPAcee Annual Conference in Ljubljana, 22-23 October 2021.

DŽINIĆ, J. (2018). Participatory Budgeting in Croatia: A Way to Improve Quality of Local Governance? In: Nemec, J., Potier, V. and De Vries, M. S. eds. Alternative Service Delivery. Brussels: IASIA/IIAS, pp. 73-81.

DŽINIĆ, J. (2022). Participatory Budgeting in Croatia: A Mixed Bag of Good, Bad, and Indifferent. In: De Vries, M. S., Nemec, J. and Špaček, D. eds. International Trends in Participatory Budgeting: Between Trivial Pursuits and Best Practices. Cham: Palgrave Macmillan, pp. 113-129. DOI: https:// doi.org/10.1007/978-3-030-79930-4_6.

DŽINIĆ, J., MURRAY SVIDROŇOVÁ, M. and MARKOWSKA-BZDUCHA, E. (2016). Participatory Budgeting: A Comparative Study of Croatia, Poland, and Slovakia. In: The NISPAcee Journal of Public Administration and Policy. Vol. 9, No. 1, pp. 31-56. DOI: https://doi.org/10.1515/nispa-2016-0002. FINNEMORE, M. and SIKKINK, K. (1998). International Norm and Political Change. In: International Organization, Vol. 52, No. 4, pp. 887-917. DOI: https://doi.org/10.1162/002081898550789.

FÖLSCHER, A. (2007). Participatory Budgeting in Central and Eastern Europe. In: Shah, A. ed. Participatory Budgeting: Public Sector Governance and Accountability. Washington: The International Bank for Reconstruction and Development/The World Bank, pp. 127-156.

GARAJ, M. and BARDOVIČ, J. (2020). Participatory Budgeting: The Case of the Slovak Republic. In: Annales Universitatis Mariae-Curie Skłodowska, sectio $K$ - Politologia. Vol. 27, No. 2, pp. 59-73. DOI: https://doi. org/10.17951/k.2020.27.2.59-73.

GAŠPARÍK, J. (2021). Brnenský participatívny rozpočet $\mathrm{z}$ pohladu teoretických východísk. In: Cibík, L., Brix, R., Novák, M. and Michal, S. eds. PUBLICY 2021 - čast' II. Zborník príspevkov z medzinárodnej vedeckej konferencie. Trnava: Fakulta sociálnych vied, Univerzita sv. Cyrila a Metoda v Trnave, pp. 86-96.

GEISSLER, R., HAMMERSCHMID, G. and RAFFER, C. eds. (2021). Local Public Finance. Cham: Springer. DOI: https://doi.org/10.1007/978-3-03067466-3.

GENDZWIŁŁ, A., KJÆR, U. and STEYVERS, K. (2022). "Happily Ever After”? Comparing Local Elections and Voting in 40 European Countries. In: Gendzwiłł, A., Kjær, U. and Steyvers, K. eds. The Routledge Handbook of Local Elections and Voting in Europe. London/New York: Routledge, pp. 489-531. 
GOLDFRANK, B. (2007). Lessons from Latin America's Experience with

Participatory Budgeting. In: Shah, A. ed. Participatory Budgeting: Public Sector Governance and Accountability. Washington: The International Bank for Reconstruction and Development/The World Bank, pp. 91-126. GOLDFRANK, B. (2012). The World Bank and the Globalization of Participatory Budgeting. In: Journal of Public Deliberation. Vol. 8, No. 2, Art. 7. DOI: https://doi.org/10.16997/jdd.143.

GONDÁŠOVÁ, L. and SVIDROŇOVÁ, M. M. (2016). Participatory Budgeting as an Innovation in Local Public Services Delivery: The Slovak Case. In: Špalková, D. and Matějová, L. eds. Current Trends in Public Sector Research: Proceedings of the 20th International Conference. Brno: Masaryk University, pp. 248-256.

HEINELT, H., MAGNIER, A., CABRIA, M. and REYNAERT, H. eds. (2018). Political Leaders and Changing Local Democracy. The European Mayor. Cham: Palgrave Macmillan. DOI: https://doi.org/10.1007/978-3-31967410-0.

HERNANDEZ-MEDINA, E. (2007). Globalizing Participation: "Exporting" the Participatory Budgeting Model from Brazil to the Dominican Republic. In: Berkeley Journal of Sociology. Vol. 51, No. 1, pp. 69-118.

HORDIJK, M. (2005). Participatory Governance in Peru: Exercising Citizenship. In: Environment and Urbanization. Vol. 17, No. 1, pp. 219236. DOI: https://doi.org/10.1177/095624780501700111.

HRABINOVÁ, A. (2020). Transparentnost' výkonu samosprávy a otvorené dáta. In: Klimovský, D. ed. Participatívne procesy $v$ praxi: čítanka participatívnej tvorby verejných politík. Bratislava: Ministerstvo vnútra SR/Úrad splnomocnenca vlády SR pre rozvoj občianskej spoločnosti, pp. 219-263.

JUNJAN V. (2020a). Capacity Building. In: Farazmand A. ed. Global Encyclopedia of Public Administration, Public Policy, and Governance. Cham: Springer. DOI: https://doi.org/10.1007/978-3-319-31816-5_3004-1.

JUNJAN, V. (2020b). Democratic Governance in Turbulent Times. In: Asia Pacific Journal of Public Administration. Vol. 42, No. 1, pp. 15-16. DOI: https://doi.org/10.1080/23276665.2020.1733284.

KEMPA, J. and KOZŁOWSKI, A. R. (2020). Participatory Budget as a Tool Supporting the Development of Civil Society in Poland. In: The NISPAcee Journal of Public Administration and Policy. Vol. 13, No. 1, pp. 61-79. DOI: https://doi.org/10.2478/nispa-2020-0003.

KERSTING, N., GASPARIKOVA, J., IGLESIAS, A. and KRENJOVA, J. (2016). Local Democratic Renewal by Deliberative Participatory Instruments: 
Participatory Budgeting in Comparative Study. In: Kuhlmann, S. and Bouckaert, G. eds. Local Public Sector Reforms in Times of Crisis: National Trajectories and International Comparisons. London: Palgrave Macmillan, pp. 317-331. DOI: https://doi.org/10.1057/978-1-137-52548-2_18.

KHUTKYY, D. and AVRAMCHENKO, K. (2019). Impact Evaluation of Participatory Budgeting in Ukraine. Kiev: Ukraine Democracy Initiative. KLIMOVSKÝ et al. (2021). Participatívne rozpočtovanie (kontexty, modely a praktické skúsenosti). 1st ed. Bratislava: Wolters Kluwer. 144 pp.

KLIMOVSKÝ, D. and HRABINOVÁ, A. (2021). The Introduction of the Charter of Good Participatory Budgeting in Slovakia: The Insiders' Story. In: Politické vedy. Vol. 24, No. 4.

KLOTZ, P. (2022). The Beginning of a Beautiful Friendship? Participatory Budgeting in Hungary. In: De Vries, M. S., Nemec, J. and Špaček, D. eds. International Trends in Participatory Budgeting: Between Trivial Pursuits and Best Practices. Cham: Palgrave Macmillan, pp.149-162. DOI: https:// doi.org/10.1007/978-3-030-79930-4_8.

KLUN, M. and BENČINA, J. (2021). Predictors, Determinant Groups, and Participatory Budgeting. In: Slovak Journal of Political Sciences. Vol. 21, No. 2, pp. 186-208. DOI: https://doi.org/10.34135/sjps.210204.

KLUN, M. and BENČINA, J. (2022). Participatory Budgeting in Slovenia. In: De Vries, M. S., Nemec, J. and Špaček, D. eds. International Trends in Participatory Budgeting:Between Trivial Pursuits and BestPractices. Cham: Palgrave Macmillan, pp. 271-285. DOI: https://doi.org/10.1007/978-3030-79930-4_14.

KLUN, M. and STARE, J. (2020). Participatory Budgeting at Local Level in Slovenia. In: Hințea, C., Radu, B. V. and Suciu, R. M. eds. Collaborative Governance, Trust Building and Community Development: "Transylvanian International Conference in Public Administration" conference proceedings, 24-26 October 2019. Cluj-Napoca: Accent, pp. 174-185.

KOCIUBA, D. and RABCZEWSKA, K. (2019). Rola budżetów partycypacyjnych w zagospodarowaniu przestrzeni publicznych polskich miast - studium przypadku Lublina. In: Studia Regionalne i Lokalne. Vol. 76, No. 2, pp. 82-109.

KOZŁOWSKI, A. R. and BERNACIAK, A. (2022). Participatory Budgeting in Poland. In: De Vries, M. S., Nemec, J. and Špaček, D. eds. International Trends in Participatory Budgeting: Between Trivial Pursuits and Best Practices. Cham: Palgrave Macmillan, pp. 163-185. DOI: https://doi. org/10.1007/978-3-030-79930-4_9. 
KRENJOVA, J. and RAUDLA, R. (2013). Participatory Budgeting at the Local Level: Challenges and Opportunities for New Democracies. In: Halduskultuur - Administrative Culture. Vol. 14, No. 1, pp. 18-46.

KRENJOVA, J. and REINSALU, K. (2013). Good Governance Starts from Procedural Changes: Case study of Preparing Participatory Budgeting in the City of Tartu. In: Socialiniai tyrimai - Social Research. Vol. 32, No. 3, pp. 28-40.

KRIVOROTKO, Y. V. and SOKOL, D. V. (2022). Participatory Budgeting in Belarus. In: De Vries, M. S., Nemec, J. and Špaček, D. eds. International Trends in Participatory Budgeting: Between Trivial Pursuits and Best Practices. Cham: Palgrave Macmillan, pp. 89-111. DOI: https://doi. org/10.1007/978-3-030-79930-4_5.

KUHLMANN, S. and BOUCKAERT, G. eds. (2016). Local Public Sector Reforms in Times of Crisis: National Trajectories and International Comparisons. London: Palgrave Macmillan. DOI: https://doi.org/10.1057/978-1-13752548-2.

KUKUČKOVÁ, S. and BAKOŠ, E. (2019). Does Participatory Budgeting Bolster Voter Turnout in Elections? The Case of the Czech Republic. In: The NISPAcee Journal of Public Administration and Policy. Vol. 12, No. 2, pp. 109-129. DOI: https://doi.org/10.2478/nispa-2019-0016.

KUKUČKOVÁ, S. and POLÁCHOVÁ, M. (2021). The Impact of the D21 Method and Its Modification on Citizens' Participation in Participatory Budgeting. The Case of the Czech Republic. In: Slovak Journal of Political Sciences. Vol. 21, No. 2, pp. 117-138. DOI: https://doi.org/10.34135/sjps.210201. KURDYŚ-KUJAWSKA, A., KWIATKOWSKI, G. and OKLEVIK, O. (2019). Cities Under Participatory Construction: Scale, Dynamics, and Constraints of Participatory Budgeting. In: International Journal of Environmental \& Science Education. Vol. 14, No. 5, pp. 251-267.

LADNER, A., KEUFFER, N., BALDERSHEIM, H., HLEPAS, N., SWIANIEWICZ, P., STEYVERS, K. and NAVARRO, C. (2019). Patterns of Local Autonomy in Europe. London: Palgrave Macmillan. DOI: https://doi.org/10.1007/9783-319-95642-8.

LAZER, D. (2001). Regulatory Interdependence and International Governance. In: Journal of European Public Policy. Vol. 8, No. 3, pp. 474492. DOI: https://doi.org/10.1080/13501760110056077.

LEHTONEN, P. (2021). Policy on the Move: The Enabling Settings of Participation in Participatory Budgeting. In: Policy Studies. DOI: https:// doi.org/10.1080/01442872.2021.1895981. 
MĄCZKA, K., JERAN, A., MATCZAK, P., MILEWICZ, M. and ALLEGRETTI, G. (2021). Models of Participatory Budgeting. Analysis of Participatory Budgeting Procedures in Poland. In: Polish Sociological Review. Vol. 216, No. 4, pp. 473-492.

MADEJ, M. (2019). Participatory Budgeting in the Major Cities in Poland Case Study of 2018 Editions. In: Politics in Central Europe. Vol. 15, No. 2, pp. 257-277. DOI: https://doi.org/10.2478/pce-2019-0017.

MÆRØE, A. R., NORTA, A., TSAP, V. and PAPPEL, I. (2021). Increasing Citizen

Participation in E-participatory Budgeting Processes. In: Journal of Information Technology \& Politics. Vol. 18, No. 2, pp. 125-147. DOI: https://doi.org/10.1080/19331681.2020.1821421.

MAŠKARINEC, P. (2020). Quality of Life and Women's Descriptive Representation: Female Emergence and Success in the 2018 Czech Local Elections. In: Central European Journal of Politics. Vol. 6, No. 2, pp. 23-43. DOI: https://doi.org/10.24132/cejop_2020_2.

MAŠKARINEC, P. and KLIMOVSKÝ, D. (2016). Independent Candidates in the Local Elections of 2014 in the Czech Republic and Slovakia: Analysis of Determinants of Their Successfulness. In: Lex Localis - Journal of Local Self-Government. Vol. 14, No. 4, pp. 853-871. D0I: https://doi. org/10.4335/14.4.853-871(2016).

MELENCHUK, A. (2021). Inclusive Local Digital Participation in Georgia, Moldova, and Ukraine. Policy Paper. German Marshall Fund of the United States.

MELGAR, T. R. (2014). A Time of Closure? Participatory Budgeting in Porto Alegre, Brazil, after the Workers' Party Era. In: Journal of Latin American Studies. Vol. 46, No. 1, pp. 121-149. DOI: https://doi.org/10.1017/ S0022216X13001582.

MESEGUER, C. (2004). What Role for Learning? The Diffusion of Privatisation in OECD and Latin American Countries. In: Journal of Public Policy. Vol. 24, No. 3, pp. 299-325. DOI: https://doi.org/10.1017/S0143814X04000182. MIKUŠ, D., BRIX, R. and ŠMATLÁNEK, D. (2021). Specifications of Participatory Budgeting in Visegrad Group States and Possible Implementations for Slovakia. In: Slovak Journal of Political Sciences. Vol. 21, No. 2. pp. 161185. DOI: https://doi.org/10.34135/sjps.210203.

MILOSAVLJEVIĆ, M., SPASENIĆ, Ž. and BENKOVIĆ, S. (2022). Participatory Budgeting in Serbia. In: De Vries, M. S., Nemec, J. and Špaček, D. eds. International Trends in Participatory Budgeting: Between Trivial Pursuits and Best Practices. Cham: Palgrave Macmillan, pp. 229-245. DOI: https:// doi.org/10.1007/978-3-030-79930-4_12. 
MILOSAVLJEVIĆ, M., SPASENIĆ, Ž., BENKOVIĆ, S. and DMITROVIĆ, V. (2020). Participatory Budgeting in Serbia: Lessons Learnt from Pilot Projects. In: Lex Localis - Journal of Local Self-Government. Vol. 18, No. 4, pp. 9991021. DO: https://doi.org/10.4335/18.3.999-1021(2020).

MINÁRIK, P. (2020). Participatory Budgeting and Traditional Participation in Czech Municipalities. In: Slovak Journal of Political Sciences. Vol. 20, No.

1, pp. 29-47. DOI: https://doi.org/10.34135/sjps.200102.

MURRAY SVIDROŇOVÁ, M. and KLIMOVSKÝ, D. (2022). Participatory Budgeting in Slovakia: Recent Development, Present State, and Interesting Cases. In: De Vries, M. S., Nemec, J. and Špaček, D. eds. International Trends in Participatory Budgeting: Between Trivial Pursuits and Best Practices. Cham: Palgrave Macmillan, pp. 247-269. DOI: https:// doi.org/10.1007/978-3-030-79930-4_13.

NEMEC, J. (2014). Comparative Analysis of Public Administrations Reforms in Former Socialist Countries of Central and Eastern Europe. In: International Journal of Civil Service Reform \& Practice. Vol. 2, No. 4, pp. 93-113.

NEMEC, J., ŠPAČEK, D. and DE VRIES, M. S. (2022). Unraveled Practices of Participatory Budgeting in European Democracies. In: De Vries, M. S., Nemec, J. and Špaček, D. eds. International Trends in Participatory Budgeting: Between Trivial Pursuits and Best Practices. Cham: Palgrave Macmillan, pp. 287-313. DOI: https://doi.org/10.1007/978-3-03079930-4_15.

NYLEN, W. R. (2002). Testing the Empowerment Thesis: The Participatory Budget in Belo Horizonte and Betim, Brazil. In: Comparative Politics. Vol. 34, No. 2, pp. 127-145. DOI: https://doi.org/10.2307/4146934.

OLIVEIRA, O. P. (2017). International Policy Diffusion and Participatory Budgeting. New York: Palgrave Macmillan. DOI: https://doi. org/10.1007/978-3-319-43337-0.

PINNINGTON, E., LERNER, J. and SCHUGURENSKY, D. (2009). Participatory Budgeting in North America: The Case of Guelph, Canada. In: Journal of Public Budgeting, Accounting \& Financial Management. Vol. 21, No. 3, pp. 455-484. DOI: https://doi.org/10.1108/JPBAFM-21-03-2009-B005.

POLKO, A. (2015). Models of Participatory Budgeting: The Case Study of a Polish City. In: Journal of Economics and Management. Vol. 19, No. 1, pp. 34-44.

POPŁAWSKI, M. (2020). COVID-19 and Direct Contact-Free Democracy: Experiences from Poland. In: Przegląd Prawa Konstytucyjnego. Vol 58, No. 6, pp. 603-614. DOI: https://doi.org/10.15804/ppk.2020.06.49. 
POPŁAWSKI, M. and GAWŁOWSKI, R. (2019). Participatory Budgeting as a Democratic Innovation in Powiats? In: The Copernicus Journal of Political Studies. Vol. 2019, No. 2, pp. 59-74. DOI: https://doi.org/10.12775/ CJPS.2019.012.

RADZIK-MARUSZAK, K. and BÁTOROVÁ, M. (2015). Citizen Participation and Engagement in Urban Governance: Perception of Finnish and Polish Local Officials. In: The NISPAcee Journal of Public Administration and Policy. Vol. 8, No. 1, pp. 85-110. DOI: https://doi.org/10.1515/nispa-2015-0005. RÖCKE, A. (2014). Framing Citizen Participation: Participatory Budgeting in France, Germany, and the United Kingdom. Basingstoke: Palgrave Macmillan. DOI: https://doi.org/10.1057/9781137326669.

ROGERS, E. M. (2010). Diffusion of Innovations. 4th edn. New York: The Free Press.

ŠABOVIC, M. T., MILOSAVLJEVIĆ, M. and BENKOVIĆ, S. (2021). Participation of Citizens in Public Financial Decision-Making in Serbia. In: Slovak Journal of Political Sciences. Vol. 21, No. 2, pp. 209-229. D0I: https://doi. org/10.34135/sjps.210205.

SEDMIHRADSKÁ, L., KUKUČKOVÁ, S. and BAKOŠ, E. (2022). Project-Oriented Participatory Budgeting in the Czech Republic. In: De Vries, M. S., Nemec, J. and Špaček, D. eds. International Trends in Participatory Budgeting: Between Trivial Pursuits and Best Practices. Cham: Palgrave Macmillan, pp. 131-147. DOI: https://doi.org/10.1007/978-3-030-79930-4_7.

SHAH, A. (2007b). Overview. In: Shah, A. ed. Participatory Budgeting: Public Sector Governance and Accountability. Washington: The International Bank for Reconstruction and Development/The World Bank, pp. 1-18.

SHAH, A. ed. (2007a). Participatory Budgeting: Public Sector Governance and Accountability. Washington: The International Bank for Reconstruction and Development/The World Bank.

SIMMONS, B. A. and ELKINS, Z. (2004). The Globalization of Liberalization: Policy Diffusion in the International Political Economy. In: American Political Science Review. Vol. 98, No. 1, pp. 171-189. DOI: https://doi. org/10.1017/S0003055404001078.

SINTOMER, Y., HERZBERG, C. and RÖCKE, A. (2008). Participatory Budgeting in Europe: Potentials and Limitations of Participatory Budgeting. In: International Journal of Urban and Regional Research. Vol. 32, No. 1, pp. 164-178. DOI: https://doi.org/10.1111/j.1468-2427.2008.00777.x. SINTOMER, Y., HERZBERG, C. and RÖCKE, A. (2013). Participatory Budgeting in Europe. Democracy and Public Service in the 21st Century. Farnham: Ashgate. 
SINTOMER, Y., HERZBERG, C., ALLEGRETTI, G. and RÖCKE, A. (2010). Learning from the South: Participatory Budgeting Worldwide. An Invitation to Global Cooperation. Dialog Global Series, No. 25. Bonn: InWEnt - Capacity Building International/Service Agency Communities in One World.

SOCIAL INNOVATION CENTRE. (2020). Big Step Forward on the Implementation of Participatory Budgeting (PB) in Latvia. [online]. Available at: http://socialinnovation.lv/en/liels-solis-preti-lidzdalibasbudzeta-ieviesanai-latvija/.

SOUKOP, M., ŠARADÍN, P. and ZAPLETALOVÁ, M. (2021). Participatory

Budgeting: Case Study of Possible Causes of Failures. In: Slovak Journal of Political Sciences. Vol. 21, No. 2, pp. 139-160. DOI: https://doi. org/10.34135/sjps.210202.

ŠRAMEL, B. (2018). The Legal Basis of Civic Participation in Slovakia after 1989. In: Marczewska-Rytko, M., Aksiuto, K., Maj, D. and Pomarański, M. eds. Civic Participation in the Visegrad Group Countries after 1989. Lublin: Maria Curie-Skłodowska University Press, pp. 173-188.

ŠVALJEK, S., RAŠIĆ BAKARIĆ, I. and SUMPOR, M. (2019). Citizens and the City: The Case for Participatory Budgeting in the City of Zagreb. In: Public Sector Economics. Vol. 43, No. 1, pp. 21-48. DOI: https://doi.org/10.3326/ pse.43.1.4.

SZEŚCIŁO, D. (2015). Participatory Budgeting in Poland: Quasi-Referendum Instead of Deliberation. In: Hrvatska i komparativna javna uprava Croatian and Comparative Public Administration. Vol. 15, No. 2, pp. 373388.

TEIVAINEN, T. (2010). The World Social Forum and Global Democratisation: Learning from Porto Alegre. In: Third World Quarterly. Vol. 23, No. 4, pp. 621-632. DOI: https://doi.org/10.1080/0143659022000005300.

TIPPELT, H. (2017). Otevřená pevnost. K filosofickým aspektům přímé demokracie. In: Central European Journal of Politics. Vol. 3, No. 1, pp. 5071.

TOMÁŠKOVÁ, E. and BUZKOVÁ, R. (2020). Participatory Budgeting in Brno: Inspiration for Other Cities? In: European Research Studies Journal. Vol. 23, No. 4, pp. 758-770. DOI: https://doi.org/10.35808/ersj/1712.

USAID. (2020). Engaging the Community in Planning for the Future. Published on 20 October 2020. Online access: https://www.usaid.gov/northmacedonia/news-information/news/engaging-community-planningfuture. 
WAMPLER, B. (2004). Expanding Accountability through Participatory Institutions: Mayors, Citizens, and Budgeting in Three Brazilian Municipalities. In: Latin American Politics and Society. Vol. 46, No. 2, pp. 73-99. DOI: https://doi.org/10.1111/j.1548-2456.2004.tb00276.x.

WAMPLER, B. (2007). Participatory Budgeting in Brazil: Contestation, Cooperation, and Accountability. University Park: The Pennsylvania University State Press.

WAMPLER, B. and AVRITZER, L. (2005). The Spread of Participatory Democracy in Brazil: From Radical Democracy to Participatory Good Government. In: Journal of Latin American Urban Studies. Vol. 7, No. 7, pp. 37-52.

WAMPLER, B. and GOLDFRANK, B. (2022). The Rise, Spread, and Decline of Brazil's Participatory Budgeting: The Arc of a Democratic Innovation. Cham: Palgrave Macmillan.

WAMPLER, B., MCNULTY, S. and TOUCHTON, M. (2018). Participatory Budgeting: Spreading Across the Globe. Boise/Lancaster/Miami: Boise State University/Frank Marshall College/University of Miami.

WOLLMANN, H., KOPRIĆ, I. and MARCOU, G. eds. (2016). Public and Social Services in Europe: From Public and Municipal to Private Sector Provision. London: Palgrave Macmillan. DOI: https://doi.org/10.1057/978-1-13757499-2.

WU, X., RAMESH, M. and HOWLETT, M. (2015). Policy Capacity: A Conceptual Framework for Understanding Policy Competences and Capabilities. In: Policy \& Society. Vol. 34, Nos. 3-4, pp. 165-171. DOI: https://doi. org/10.1016/j.polsoc.2015.09.001.

ZAPLETALOVÁ, M., SOUKOP, M. and ŠARADÍN, P. (2020). Praxe participativních rozpočtů v České republice. Případová studie obce $\mathrm{s}$ rozšířenou působností Semily. In: Sociológia. Vol. 52, No. 2, pp. 180-200. DOI: DOI: https://doi.org/10.31577/sociologia.2020.52.2.8.

ZAWADZKA-PĄK, U. K. and TOMÁŠKOVÁ, E. (2019). Legal and Axiological Aspects of Participatory Budgeting Procedure in Poland and the Czech Republic. In: Białostockie Studia Prawnicze. Vol. 24, No. 3, pp. 165-175. DOI: https://doi.org/10.15290/bsp.2019.24.03.13. 